\title{
Synergistic approach in diagnosing endometrial disease in women with postmenopausal bleeding
}

\author{
Jiten Sharma $^{1 *}$, Bishan Dhiman', Nishi Sud ${ }^{1}$, Anupriya Kaushik ${ }^{2}$
}

\begin{abstract}
${ }^{1}$ Department of Obstetrics and Gynecology, Kamla Nehru State Hospital for Mother and Child, Indira Gandhi Medical College, Shimla, Himachal Pradesh, India

${ }^{2}$ Department of Pedodontics and Preventive Dentistry, MN DAV Dental College, Tatul, Solan, Himachal Pradesh, India
\end{abstract}

Received: 13 July 2017

Revised: 17 July 2017

Accepted: 08 August 2017

\section{*Correspondence:}

Dr. Jiten Sharma,

E-mail: jitensharma8@gmail.com

Copyright: ( ) the author(s), publisher and licensee Medip Academy. This is an open-access article distributed under the terms of the Creative Commons Attribution Non-Commercial License, which permits unrestricted non-commercial use, distribution, and reproduction in any medium, provided the original work is properly cited.

\begin{abstract}
Background: All women with postmenopausal uterine bleeding mandate examination for endometrial diseases especially endometrial carcinoma. In current scenario, hysteroscopy has replaced traditional Dilatation and Curettage as diagnostic procedure of choice. However, office endometrial sampling with pipelle combined with vaginal ultrasonography being easier and less expensive is recommended. Aim and objectives of the study was to evaluate the combined use of vaginal ultrasonography and office endometrial sampling for the diagnosis of endometrial disease in postmenopausal women with uterine bleeding.

Methods: One hundred consecutive postmenopausal women presenting with uterine bleeding were enrolled in the study. Vaginal ultrasonography was used to measure the endometrial thickness. Endometrial sampling was done using endometrial biopsy pipelle, as office procedure, in the OPD examination room. The sample was sent for Histopathological Examination (HPE), The accuracy of vaginal ultrasound and pipelle was measured.

Results: In $21 \%$ patients, endometrial carcinoma was found, endometrial hyperplasia in $26 \%$, atrophic endometrium in $18 \%$, endometrial polyp in $10 \%$ and no specific pathology in $20 \%$. Endometrial thickness measured by Transvaginal ultrasound ranged from $1 \mathrm{~mm}$ to $28 \mathrm{~mm}$ with mean of $10.16 \mathrm{~mm}$ and median of $11.5 \mathrm{~mm}$. The mean endometrial thickness in subgroup without disease was $5.26 \pm 3.8 \mathrm{~mm}$, with benign disease $12.8 \pm 3.1 \mathrm{~mm}$ and in carcinoma $16.97 \pm 5.6 \mathrm{~mm}$. All cases with carcinoma had endometrial thickness exceeding $5 \mathrm{~mm}$ (range $5.7 \mathrm{~mm}$ to $28 \mathrm{~mm})$.

Conclusions: The study illustrates that by combined use of Trans Vaginal Sonography (TVS) and office endometrial sampling, sufficient diagnostic information was obtained for women with postmenopausal bleeding, obviating the need for more invasive diagnostic procedures.
\end{abstract}

Keywords: Endometrial sampling, Trans vaginal sonography, Postmenopausal bleeding

\section{INTRODUCTION}

Menopause, the end of ovulation and menstrual periods, naturally occurs for most women at the age of 40-55 years. It is a gradual, process spanning 1 to 2 years.
According to Berek and Novak's textbook of Gynecology, in the absence of hormone therapy, any bleeding after menopause (classically defined as absence of menses for 1 year) is referred to as postmenopausal bleeding (PMB) and it should prompt evaluation with 
endometrial sampling. ${ }^{1}$ It accounts for $5 \%$ of all gynecologic office visits. Moreover, a reported $25 \%$ of gynecologic surgeries involve abnormal uterine bleeding. ${ }^{2}$ Postmenopausal bleeding accounts for about $5 \%$ of all out patients and is a common indication for referral to rapid access clinics from general practice because of the fear of underlying malignancy. ${ }^{3}$

Approximately one in 10 women will experience some bleeding after the menopause. ${ }^{4}$ All women presenting with postmenopausal bleeding must be examined for endometrial disease specially endometrial carcinoma. ${ }^{5}$ The causes of postmenopausal bleeding may be non-genital, genital, uterine or extrauterine. ${ }^{6}$ Local causes include fibroids, endometrial polyps, chronic pelvic inflammatory disease, cervical polyps, atrophic vaginitis, endometrial carcinoma and cervical carcinoma. ${ }^{7}$ Endometrial atrophy is the most common endometrial finding in women with PMB, accounting for $60-80 \%$ of such bleeding. ${ }^{8}$

Endometrial cancer is the most common gynecologic malignancy, with about 36,000 new cases diagnosed each year in the United States. ${ }^{9}$ The prevalence of endometrial cancer in women with post-menopausal bleeding ranged in various studies from $3 \%-10 \%$ and $95 \%$ of these women presented with post-menopausal bleeding. ${ }^{10}$ Even though the most common presenting symptom is abnormal bleeding, the prevalence of endometrial cancer in women with postmenopausal bleeding is relatively low, about $10 \%$ of patients in a recent large series. ${ }^{9}$

Ultrasonography in the diagnosis of postmenopausal disease has been studied extensively. ${ }^{11}$ Ultrasonographic imaging of the endometrium has been improved by the development and subsequent clinical application of transvaginal probes rather than abdominal ultrasonography. ${ }^{12}$ Moreover, vaginal ultrasonography has been reported to be as accurate as hysteroscopy for detecting endometrial polyps and submucosal myomas. ${ }^{13}$

Guidelines for postmenopausal women presenting with spontaneous vaginal bleeding advocate measurement of the double endometrial thickness (ET) by transvaginal ultrasound.${ }^{14}$ It has been proposed as a more convenient, relatively cheap and safe non-invasive screening method in women with PMB. ${ }^{15}$ Transvaginal ultrasonography can reliably assess endometrial thickness and uterine cavity morphology. It is a safe, rapid, highly effective, generally painless, and relatively less invasive method. It provides highly magnified images of endometrial contents. ${ }^{16}$ Furthermore, it may evaluate other pelvic organs for potential abnormalities. ${ }^{9}$ Many studies suggested that an ET of $5 \mathrm{~mm}$ or less is rarely associated with endometrial cancer. $^{3}$

However, there has been confusion on which cut-off point for ET would be suitable for excluding endometrial pathology after PMB. ${ }^{15}$ It has also been suggested that an ET of $6 \mathrm{~mm}$ is associated with the absence of sufficient tissue for histological examination in postmenopausal women, and consequently these women could be spared endometrial sampling and thus the risk, discomfort and expenses of the procedure. ${ }^{11}$

Endometrial biopsy is widely used in the investigation of PMB because it provides tissue for histological diagnosis and could be easily performed, as an outpatient procedure, in most women with minor discomfort or cramping. ${ }^{17}$ The role of EB alone as a sufficient method to rule out endometrial cancer is debatable, with some studies showing that it results in inadequate samples in up to $16 \%$ of cases, and its sensitivity in detecting endometrial hyperplasia and cancer could be as low as $67 \%$ and $81 \%$, respectively. ${ }^{3}$

Despite the reassuring findings, the amount of tissue obtained in office sampling varies considerably, in case of insufficient samples, the guidelines of Dutch society of Obstetrics and Gynecology leaves further testing to the discretion of the gynecologist. ${ }^{18}$ The value of EB is limited by uncertainty about the origin of the tissue, which is obtained in a blind procedure, and the difficulty of obtaining adequate specimens in some women. ${ }^{19}$

Whether TVS or EB is used initially depends on the physician's assessment of patient risk, the nature of the physician's practice, the availability of high-quality sonography, and women's preference. Similar sensitivities for detecting endometrial cancer are reported for TVS when an endometrial thickness of $5 \mathrm{~mm}$ or less is considered as normal and for EB when sufficient tissue is obtained..$^{20}$

In the present study, endometrial sampling will be done using endometrial Pipelle because it is comparable to the Novak curette in obtaining adequate tissue and is significantly less painful. ${ }^{21}$ This pipelle would be inserted into the uterine cavity without dilatation and after insertion, piston is withdrawn.

Withdrawal of this piston would create a negative pressure and thus endometrial tissue would be aspirated into the canula, as it is rotated $360^{\circ}$ through the endometrial cavity. The whole procedure was repeated twice. When endocavity fluid was aspirated, the whole procedure was repeated until no more fluid was aspirated; then two more aspirations were performed. The diagnostic information obtained by combining the use of TVS and office procedure for endometrial sampling could obviate the need for more invasive diagnostic procedures.

\section{METHODS}

This prospective study was conducted in the Department of Obstetrics and Gynecology, Kamla Nehru State Hospital for Mother and Child, IGMC, (KNSH For M and C), Shimla, Himachal Pradesh with effect from (w.e.f.) $1^{\text {st }}$ August 2015 to $31^{\text {st }}$ July, 2016.100 cases of 
Postmenopausal Bleeding (PMB) were taken who attend the Gynae OPD at KNSH for M and C, Shimla, HP.

Women with Post-Menopausal Bleeding were included in the study and those who were diagnosed cases of genital organ malignancy or undergoing current hormone replacement therapy were excluded from the study.

After taking the detailed history and written informed consent from the patients, routine investigations i.e. hemoglobin $(\mathrm{Hb})$ and urine for albumin and sugar were done in the hospital laboratory of the hospital. Papanicolaou (PAP) Smear was taken.

After this, the same patient was taken for TVS in the Radiology Department where detailed ultrasound examination was performed. The ultrasound machine used was LOGIQ P6 from GE health care. Sonographic report was collected for further record and analysis.

Thereafter, patient's detailed examination i.e. per abdomen (P/A), per speculum (P/S) was done and then bimanual examination was performed. Endometrial sampling was done using endometrial biopsy pipelle as office procedure in the OPD examination room. The endometrial sample which was collected with pipelle was sent for histopathological examination (HPE) to the Pathology Department at Indira Gandhi Medical College (IGMC) Shimla, HP.

Report of HPE was collected, recorded and kept for final analysis. Definitive treatment was advised after HPE and TVS reports.

\section{RESULTS}

In 74 patients (74\%), PAP smear could not be performed as they presented with active bleeding to OPD, however per speculum examination was normal. 12 patients (12\%) had inflammatory smear on PAP smear examination. In 1 subject $(1 \%)$, the smear was not satisfactory for evaluation.

31 patients $(31 \%)$ had endometrial thickness, measured on TVS, in the range of $10-15 \mathrm{~mm}$ and only 1 subject (1\%) had ET of $>25 \mathrm{~mm}$.

Table 1: Per speculum examination and pap smear results of patients $(n=100)$.

\begin{tabular}{|lll|}
\hline $\begin{array}{l}\text { Per Speculum } \\
\text { Examination }\end{array}$ & PAP Smear Result & $\begin{array}{l}\text { No. of } \\
\text { Patients }\end{array}$ \\
\hline $\begin{array}{l}\text { Grossly normal, } \\
\text { bleeding present }\end{array}$ & $\begin{array}{l}\text { Bleeding hence could } \\
\text { not be performed }\end{array}$ & 74 \\
\hline Grossly normal & Inflammatory & 12 \\
\hline Grossly normal & Infective & 7 \\
\hline Grossly normal & No specific pathology & 6 \\
\hline Grossly normal & Not satisfactory & 1 \\
\hline Total & & 100 \\
\hline
\end{tabular}

Table 2: Endometrial thickness on transvaginal sonography of patients $(n=100)$.

\begin{tabular}{|l|l|}
\hline $\begin{array}{l}\text { Endometrial thickness on TVS } \\
(\mathbf{m m})\end{array}$ & No. of patients \\
\hline $1-5$ & 27 \\
\hline $5-10$ & 23 \\
\hline $10-15$ & 31 \\
\hline $15-20$ & 13 \\
\hline $20-25$ & 5 \\
\hline$>25$ & 1 \\
\hline Total & 100 \\
\hline
\end{tabular}

Table 3: Endometrial sampling (histopathologic examination) of patients $(n=100)$.

\begin{tabular}{|ll|}
\hline $\begin{array}{l}\text { Endometrial curetting } \\
\text { (microscopic examination) }\end{array}$ & No. of the patients \\
\hline Scanty & 5 \\
\hline Atrophic & 34 \\
\hline No specific findings & 12 \\
\hline Endometrial Polyp & 12 \\
\hline Endometrial Hyperplasia & 20 \\
\hline Endometrial Carcinoma & 17 \\
\hline Total & 100 \\
\hline
\end{tabular}

Endometrial carcinoma was detected in 17 patients (17\%), endometrial hyperplasia in 20 patients $(20 \%)$, endometrial polyp in 12 patients $(12 \%)$ and 34 patients (34\%) had atrophic endometrium.

After applying spearman test for correlation, the correlation coefficient was 0.327 with p-value of 0.001 which is significant. This implies that with increasing numbers of episodes of postmenopausal bleeding chances of having an abnormal finding on HPE increases.

42 patients $(42 \%)$ belonged to lower middle class-3, 23 patients $(23 \%)$ belonged each to upper middle class- 2 and 22 patients $(22 \%)$ to upper lower class-4, 7 patients $(7 \%)$ belonged to lower class-5 and only 6 patients $(6 \%)$ belonged to upper class-1. Further it was noticed that $38.1 \%$ of endometrium carcinoma cases ,53.8\% of endometrial hyperplasia cases, $38.9 \%$ of atrophic endometrium cases and $50 \%$ of endometrial polyps belonged to lower middle class-3.

Endometrial thickness on TVS in patients with carcinoma endometrium was in the range of 5.7-21 mm with mean of $13.7 \pm 3.97 \mathrm{~mm}$. The mean ET of patients with endometrial hyperplasia was $16.88 \pm 4.92$, with endometrial polyp was between $9-14 \mathrm{~mm}$, with atrophic endometrium had ET ranging between $2-7 \mathrm{~mm}$.

Patients with no specific pathology had ET ranging between $7-18 \mathrm{~mm}$. Finally, patients in whom nil or scanty specimen insufficient to give any opinion was obtained had ET ranging between $1-4 \mathrm{~mm}$. It was noted that none of the carcinoma endometrium patients had ET $<5 \mathrm{~mm}$. 
Table 4: Correlation between number of episodes of bleeding with histopathologic examination findings of patients.

\begin{tabular}{|c|c|c|c|c|}
\hline & & & No. of episodes & E/C (HPE) \\
\hline \multirow{6}{*}{ Spearman's rho } & \multirow{3}{*}{ No. of episodes } & Correlation Coefficient & 1.000 & $0.327^{* *}$ \\
\hline & & Sig. (2-tailed) & - & 0.001 \\
\hline & & $\mathrm{N}$ & 100 & 100 \\
\hline & \multirow{3}{*}{ E/C(HPE) } & Correlation Coefficient & $0.327^{* *}$ & 1.000 \\
\hline & & Sig. (2-tailed) & 0.001 & - \\
\hline & & $\mathrm{N}$ & 100 & 100 \\
\hline
\end{tabular}

**. Correlation is significant at the 0.01 level (2-tailed).

Table 5: Socioeconomic (modified kuppuswamy scale) class wise distribution of HPE findings of patients ( $\mathrm{n}=100)$.

\begin{tabular}{|llllllll|}
\hline $\begin{array}{l}\text { Modified } \\
\text { kuppuswamy scale }\end{array}$ & $\begin{array}{l}\text { Carcinoma } \\
\text { endometrium }\end{array}$ & $\begin{array}{l}\text { Endometrial } \\
\text { hyperplasia }\end{array}$ & $\begin{array}{l}\text { Endometrial } \\
\text { polyp }\end{array}$ & $\begin{array}{l}\text { Atrophic } \\
\text { endometrium }\end{array}$ & $\begin{array}{l}\text { No specific } \\
\text { pathology }\end{array}$ & $\begin{array}{c}\text { Scanty } \\
\text { Total }\end{array}$ \\
\hline U-1 & 3 & 0 & 1 & 2 & 0 & 0 & 6 \\
\hline UM-2 & 1 & 8 & 0 & 7 & 4 & 3 & 23 \\
\hline LM-3 & 9 & 8 & 6 & 12 & 6 & 1 & 42 \\
\hline UL-4 & 2 & 3 & 4 & 11 & 1 & 1 & 22 \\
\hline L-5 & 2 & 1 & 1 & 2 & 1 & - & 7 \\
\hline Total & 17 & 20 & 12 & 34 & 12 & 5 & 100 \\
\hline
\end{tabular}

Table 6: Comparison of age, HPE findings and ET measured on TVS of patients $(n=100)$.

\begin{tabular}{|lll|l|}
\hline Histopathology examination & Age variation (years) & Endometrial thickness by TVS (mm) & $\begin{array}{l}\text { Number of } \\
\text { patients }\end{array}$ \\
\hline Scanty & $48-70(57.0 \pm 10.68)$ & $1-4(2.2 \pm 1.09)$ & 5 \\
\hline Atrophic endometrium & $42-80(63.32 \pm 9.68)$ & $2-7(4.8 \pm 2.4)$ & 34 \\
\hline No specific pathology & $57-68(61.67 \pm 3.55)$ & $7-18(12.12 \pm 3.71)$ & 12 \\
\hline Endometrial polyp & $45-71(60.5 \pm 7.55)$ & $9-14(11.69 \pm 1.66)$ & 12 \\
\hline Endometrial hyperplasia & $48-71(60.45 \pm 5.52)$ & $10-28(16.88 \pm 4.92)$ & 20 \\
\hline Carcinoma endometrium & $49-76(60.82 \pm 7.44)$ & $5.7-21(13.7 \pm 3.97)$ & 17 \\
\hline Total & $42-80(61.47 \pm 7.8)$ & & 100 \\
\hline
\end{tabular}

Table 7: Comparison of sensitivities and negative predictive values of et measurement with TVS with malignant finding on HPE.

\begin{tabular}{|llll|}
\hline ET cut off $(\mathbf{m m})$ & No. of malignancies missed & Sensitivity $(\%)$ & Negative predictive value $(\%)$ \\
\hline$>2$ & 0 & 100 & 100 \\
\hline$>3$ & 0 & 100 & 100 \\
\hline$>4$ & 0 & 100 & 100 \\
\hline 5 & 0 & 100 & 100 \\
\hline$>6$ & 1 & 94 & 96.9 \\
\hline$>8$ & 2 & 88.2 & 94.9 \\
\hline$>10$ & 3 & 82.4 & 94 \\
\hline
\end{tabular}

Table 8: Correlation between endometrial thickness and HPE findings.

\begin{tabular}{|c|c|c|c|c|}
\hline & & & E/C (HPE) & TVS (ET in mm) \\
\hline \multirow{6}{*}{ Spearman's rho } & \multirow{3}{*}{$\mathrm{E} / \mathrm{C}(\mathrm{HPE})$} & Correlation Coefficient & 1.000 & $0.789^{* *}$ \\
\hline & & Sig. (2-tailed) & - & 0.000 \\
\hline & & $\mathrm{N}$ & 100 & 100 \\
\hline & \multirow{3}{*}{ TVS (ET in $\mathrm{mm}$ ) } & Correlation Coefficient & $0.789^{* *}$ & 1.000 \\
\hline & & Sig. (2-tailed) & 0.000 & - \\
\hline & & $\mathrm{N}$ & 100 & 100 \\
\hline
\end{tabular}

**. Correlation is significant at the 0.01 level (2-tailed). 


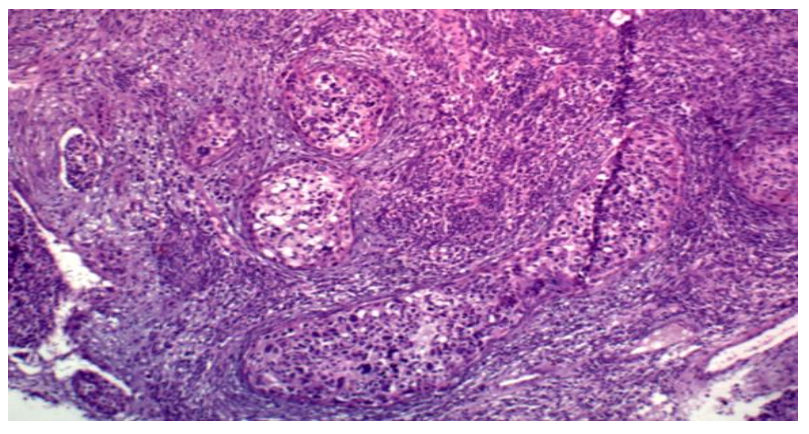

Figure 1: Endometrial carcinoma showing nests of tumor cells (10X, $\mathrm{H}$ and $\mathrm{E})$.

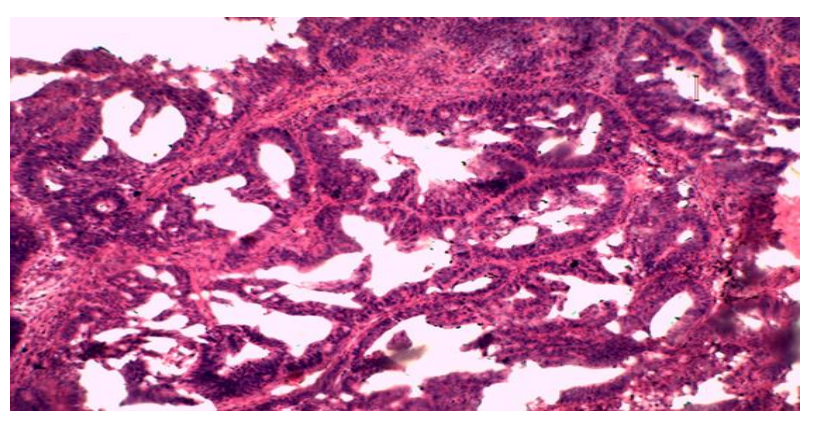

Figure 2: Endometrial hyperplasia showing stratified irregular shaped glands (40X, $\mathrm{H}$ and $\mathrm{E})$.

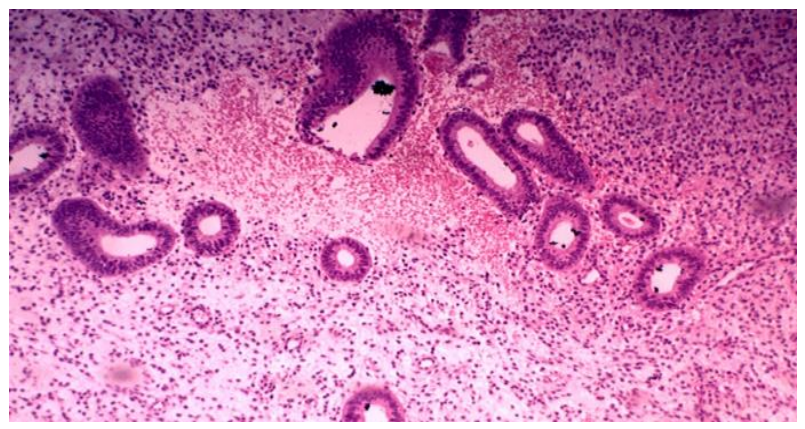

Figure 3: Anovulatory cycles: no specific pathology (10X, $\mathrm{H}$ and $\mathrm{E})$.

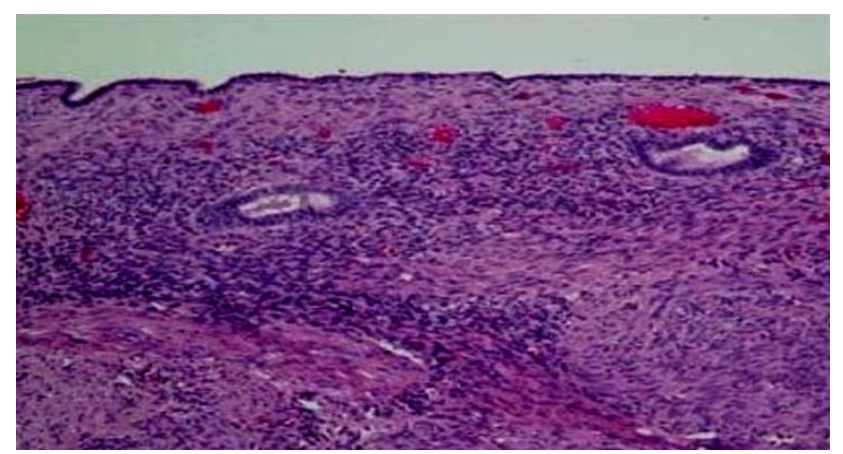

Figure 4: Atrophic endometrium (10X, H and E).

Sensitivities and negative predictive values of ET measurement by TVS in detecting an abnormal finding and malignancy both on HPE findings for ET $>5 \mathrm{~mm}$ was $100 \%$ which decreased as the cut off was raised.

Correlation between endometrial thickness and HPE findings using spearman's test for correlation was found to be 0.789 which is highly significant (p-value $<0.001$ ) which signifies that as the endometrial thickness rises the chances of getting abnormal findings on histopathology examination increases.

\section{DISCUSSION}

\section{Mean age}

In the present study, the mean age of the postmenopausal woman was $61.47 \pm 7.63$ years with the range of $42-80$ years. This is in agreement with the studies conducted by HC Van Doorn et al, M. Rusell et al, Bengt Karlsson et al and T. Van Den Bosch et al, where mean age was 62, 62, 64.0 and 59.0 years respectively. ${ }^{14,21-23}$

\section{Residential background of patients}

In the present study, it was observed that $76 \%$ of the subject belonged to rural areas and $24 \%$ belonged to urban areas. The p-value for demography of patients with respect to HPE comes out to be 0.542 which shows no significant correlation between the two variables.

\section{Parity}

In the present study, it was found that $25 \%$ of the patients had parity between $0-1,47 \%$ had parity between $2-3$ and $28 \%$ had parity $\geq 4$, which resembled closely to the study by Ayman A.A. Ewies et al. $^{24}$ However, the study conducted by Viswanathan $M$ et al had maximum patients with parity between $2-3(76.7 \%) .{ }^{25}$ As people have now started having smaller family sizes hence the reason for more cases of less parity in the present study. Also, nulliparity is a known risk factor for carcinoma endometrium, only 4 patients with nulliparity were detected in the present study.

\section{Mean time since menopause}

In the present study, the mean time since menopause was found to be $13.39 \pm 8.01$ years which coincides with the studies by Robert D. Langer et al, T. Van Den Bosch et al and Aruna N. Kekre et al Also, in all these studies no significant correlation was found between time since menopause and abnormal finding on HPE. ${ }^{19,5,26}$

\section{Number of episodes of postmenopausal bleeding}

In the present study $49 \%$ of the patients presented, with first episode of postmenopausal bleeding which coincides with the study conducted by Ayman A.A. Ewies. ${ }^{24}$ It was further found that $6.1 \%$ of the patients who presented 
with first episode of PMB had carcinoma and $27.5 \%$ of the patients who presented with multiple episodes had carcinoma endometrium. Thus, as episodes of bleeding increases chances of abnormal HPE finding increases ( $p$ value $=0.001)$. This was similar to study conducted by Mehmet C. Salman et al. ${ }^{27}$

\section{Association of medical history with histopathologic findings}

In the present study, it was found that out of all the patients 6 had both hypertension and diabetes and out of these $5(83.3 \%)$, who were overweight also had abnormal finding on HPE. However, no significant association was found when subject had diabetes, hypertension or were overweight, separately. However, in the study conducted by Doorn et al in 2004 an association between malignant finding on HPE and diabetes was found with no significant association between the diabetes, hypertension and obesity when non-malignant findings were studied. ${ }^{23}$ Giannella et al in 2014 found a positive correlation between hypertension and pathologic finding on HPE findings. ${ }^{28}$ However effect of diabetes and obesity were not studied by the latter. The study conducted by Viswanathan $\mathrm{M}$ et al 2014 was contradictory to the present study where it was found that $48 \%$ of the women with PMB were suffering from diabetes mellitus and were on treatment. ${ }^{25}$ The majority, $73.3 \%$ of the women with PMB were hypertensive and on treatment at the time of diagnosis.

\section{Socio-economic status of the patients}

In the present study, it was found that majority of the patients i.e. $87 \%$ belonged to middle class. However, only $7 \%$ and $6 \%$ belonged to lower class-5 and upper class-1, as per kuppuswamy scale 2012. This finding is due to the fact that KNSH for M and C, Shimla where this study was conducted cater mainly to the rural population. Similar results were found in study conducted by Viswanathan $\mathrm{M}$ et al 2014 where $11.7 \%$ belonged to low, $83.3 \%$ belonged to middle and $5 \%$ belonged to high class as per kuppuswamy scale $2012 .{ }^{25}$

\section{BMI of the patients}

In the present study, it was found that majority $67 \%$ of the patients belonged to normal range of BMI i.e. 18.5$24.9 \mathrm{~kg} / \mathrm{m}^{2}, 24 \%$ were overweight, $5 \%$ were obese and only $4 \%$ had BMI $<18.5 \mathrm{~kg} / \mathrm{m}^{2}$ which coincides with the study conducted by Viswanathan M et al 2014 However, the study conducted by M. Rusell et al 2016 found $57.8 \%$ of patients to be overweight and $39.8 \%$ to be obese. ${ }^{25,21}$ The study by M. Rusell et al was conducted in United Kingdom, where the average BMI of the woman is high as compared to Indian woman. ${ }^{21}$ The study by Viswanathan $\mathrm{M}$ et al was conducted in Kerala, India while present study was conducted in Shimla, Himachal Pradesh which is a hilly region with maximum population as rural and agriculture as the main occupation, so the physical activity is more, hence possibly the reason for the difference between the BMI observed in the above studies. $^{25}$

\section{Sociation of hemoglobin with histopathologic finding}

In the present study $53.1 \%$ of all patients who harbored a focal pathology had $\mathrm{Hb}<11 \mathrm{gm} \%$ while the value was $75 \%$ in the study done by Pal et al. ${ }^{29}$ This is because of the healthy dietary pattern. Also, the increasing awareness and concern amongst the general population about the risks involved with postmenopausal bleeding leads to early seeking of medical advice before hemoglobin levels start falling.

If anemia is found in a patient with postmenopausal bleeding it is mainly due to some other underlying cause other than postmenopausal bleeding.

Table 9: Comparison of mean et in different HPE findings.

\begin{tabular}{|c|c|c|c|c|c|c|}
\hline Authors & $\begin{array}{l}\text { Scanty or no } \\
\text { curetting }\end{array}$ & $\begin{array}{l}\text { Atrophic } \\
\text { endometrium }\end{array}$ & $\begin{array}{l}\text { No specific } \\
\text { findings }\end{array}$ & $\begin{array}{l}\text { Endometrial } \\
\text { polyp }\end{array}$ & $\begin{array}{l}\text { Endometrial } \\
\text { hyperplasia }\end{array}$ & $\begin{array}{l}\text { Endometrial } \\
\text { carcinoma }\end{array}$ \\
\hline $\begin{array}{l}\text { T. Van Den } \\
\text { Bosch et } \mathrm{al}^{5}\end{array}$ & $3.6 \pm 3.3 \mathrm{~mm}$ & & $10.8 \pm 7.0 \mathrm{~mm}$ & & & $22.5 \pm 8.9 \mathrm{~mm}$ \\
\hline $\begin{array}{l}\text { Bengt Karlsson } \\
\text { et } \mathrm{al}^{22}\end{array}$ & - & $3.9 \pm 2.5 \mathrm{~mm}$ & $15.1 \pm 7.9 \mathrm{~mm}$ & $12.9 \pm 8.1 \mathrm{~mm}$ & $12.0 \pm 6.0 \mathrm{~mm}$ & $21 \pm 11.8 \mathrm{~mm}$ \\
\hline $\begin{array}{l}\text { Aruna N. Kekre } \\
\text { et } \mathrm{al}^{26}\end{array}$ & $1.6 \pm 0.50 \mathrm{~mm}$ & $2.36 \pm 0.68 \mathrm{~mm}$ & $6.6 \mathrm{~mm}$ & $8.4 \pm 2.9 \mathrm{~mm}$ & $9.1 \pm 4.4 \mathrm{~mm}$ & $12.5 \pm 5.8 \mathrm{~mm}$ \\
\hline Present study & $2.2 \pm 1.09 \mathrm{~mm}$ & $4.8 \pm 2.4 \mathrm{~mm}$ & $12.12 \pm 3.71 \mathrm{~mm}$ & $11.69 \pm 1.66 \mathrm{~mm}$ & $16.88 \pm 4.92 \mathrm{~mm}$ & $13.7 \pm 3.97 \mathrm{~mm}$ \\
\hline
\end{tabular}

In the present study, the mean ET with atrophic endometrium was $4.8 \pm 2.4 \mathrm{~mm}$ which was in agreement with studies conducted by T. Van Den Bosch et al, Bengt Karlsson et al and Aruna N. Kekre et al which had ETs of

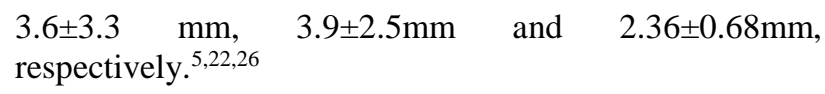


In the present study, the mean ET in endometrial carcinoma group was $13.7 \pm 3.97 \mathrm{~mm}$. Similarly, the studies conducted by T. Van Den Bosch et al, Bengt Karlsson et al and Aruna N. Kekre et al had higher ETs, $22.5 \pm 8.9 \mathrm{~mm}, 21 \pm 11.8 \mathrm{~mm}$ and $12.5 \pm 5.8 \mathrm{~mm}$, depicting thereby that as the ET rises chances of getting endometrial carcinoma increases. ${ }^{5,22,26}$

In the present study, it was found that as the endometrial thickness rises the chances of getting abnormal endometrial histological finding including endometrial carcinoma increases. This finding was similar to study of T. Van Den Bosch et al, Ilan Bruchim et al, Ayman AA. Ewies and M. Russell et al. 5,30,24,21 Thus, the present study is in strong agreement with the above studies.
Table 10: Relation of incidence of endometrial carcinoma with increasing ET.

\begin{tabular}{|lcc|}
\hline Authors & Year & $\begin{array}{l}\text { Increasing incidence of } \\
\text { endometrial carcinoma } \\
\text { with increasing ET }\end{array}$ \\
$\begin{array}{l}\text { T. Van Den } \\
\text { Bosch et } \mathrm{al}^{5}\end{array}$ & 1995 & + \\
\hline $\begin{array}{l}\text { M. Russell et al } \\
\text { A }\end{array}$ & 2015 & + \\
\hline $\begin{array}{l}\text { Ayman A.A. } \\
\text { Ewies et al }\end{array}$ & 2010 & + \\
\hline $\begin{array}{l}\text { Aruna N. Kekre } \\
\text { et al }\end{array}$ & 1997 & + \\
\hline $\begin{array}{l}\text { Ilan Bruchim et } \\
\text { al }\end{array}$ & 2004 & + \\
\hline Present study & 2016 & + \\
\hline
\end{tabular}

Table 11: Relationship between endometrial thickness and endometrial carcinoma.

\begin{tabular}{|ll|lll|}
\hline Authors & ET & No. of women & No. of cases of cancer missed & Negative predictive value \\
\hline Gull et al $^{12}$ & $\leq 4 \mathrm{~mm}$ & 163 & 1 & $99.4 \%$ \\
\hline Karlsson et al $^{22}$ & $\leq 4 \mathrm{~mm}$ & 1168 & 0 & $100 \%$ \\
\hline Ayman A.A. Ewies et al $^{24}$ & $\leq 5 \mathrm{~mm}$ & 1168 & 0 & $100 \%$ \\
\hline Ferrazzi et al $^{31}$ & $\leq 4 \mathrm{~mm}$ & & 2 & $99.8 \%$ \\
& $\leq 5 \mathrm{~mm}$ & & 4 & $99.6 \%$ \\
\hline Epstein et al $^{32}$ & $\leq 5 \mathrm{~mm}$ & 97 & 0 & $100 \%$ \\
\hline Gull et al $^{33}$ & $\leq 4 \mathrm{~mm}$ & 394 & 0 & $100 \%$ \\
\hline Present study & $\leq 5 \mathrm{~mm}$ & 100 & 0 & $100 \%$ \\
& $\leq 6 \mathrm{~mm}$ & & 1 & $96.9 \%$ \\
\hline
\end{tabular}

Table 12: Comparison of final inference in various studies.

\begin{tabular}{|c|c|c|}
\hline Authors & Year & Inference \\
\hline T. Van Den Bosch ${ }^{5}$ etal & 1995 & TVS + HPE \\
\hline Doorn et $\mathrm{al}^{14}$ & 2007 & $\begin{array}{l}\text { Both TVS + HPE } \\
\text { from curettings } \\
\text { ineffective }\end{array}$ \\
\hline $\begin{array}{l}\text { Ewies and Musonda et } \\
\mathrm{al}^{24}\end{array}$ & 2010 & TVS + HPE \\
\hline Kekre et al ${ }^{26}$ & 1997 & TVS \\
\hline Tabor et $\mathrm{al}^{34}$ & 2002 & $\mathrm{USG}+\mathrm{HPE}$ \\
\hline Minagawa et al ${ }^{35}$ & 2005 & $\mathrm{USG}+\mathrm{HPE}$ \\
\hline Tsikouras et al $^{36}$ & 2008 & TVS + HPE \\
\hline Jacobs et $\mathrm{al}^{37}$ & 2011 & TVS \\
\hline Present study & 2016 & TVS + HPE \\
\hline
\end{tabular}

Present study shows that when the ET cutoff was taken as $\leq 5 \mathrm{~mm}$ then the negative predictive value was $100 \%$ as no malignancy was missed but it dropped to $96.9 \%$ when cutoff was $\leq 6 \mathrm{~mm}$ as one case of malignancy was missed. This finding was similar to study by Ayman AA. Ewies et al, Ferrazzi et al and Epstein et al, in which ET cutoff of $\leq 5 \mathrm{~mm}$ had negative predictive value of $100 \%, 100 \%$ and $99.6 \%$ respectively. ${ }^{24,31,32}$ The study by Karlsson et al, Gull et al and Ferrazzi et al used $\leq 4 \mathrm{~mm}$ as the cutoff with negative predictive values of $100 \%, 100 \%$ and $99.8 \%$ respectively. ${ }^{22,33,31}$

In the present study, it was found that TVS, which is a non-invasive process, measures only the endometrial thickness. But endometrial sampling with pipelle which is an invasive process gives Histopathologic findings. In the present study, no abnormal histopathology finding was detected in any subject who had ET $\leq 5 \mathrm{~mm}$. Thus, it was concluded that as no abnormal histopathology finding was found below ET of $5 \mathrm{~mm}$ hence patients with ET $\leq 5 \mathrm{~mm}$ can be safely followed up and should only be subjected to endometrial sampling if recurrent episodes of postmenopausal bleeding occurs. However, for final confirmatory result HPE is must as measurement of ET by TVS cannot differentiate between benign and malignant HPE findings. The same was inferred by study conducted by T. Van Den Bosch et al, Tabor et al Minagawa et al, Tsikouras et al and Ewies and Musonda et al concluded that Ultrasound and HPE both are effective for diagnosing pathology when used together. $5,34-36,24$

Doorn et al concluded that in women with postmenopausal bleeding and a non-reassuring 
transvaginal ultrasound evaluation, a non-diagnostic office endometrial sample does not rule out endometrial cancer and further endometrial sampling is advisable. ${ }^{14}$ However, Studies by Kekre et al and Jacobs et al showed that TVS screening alone for endometrial cancer has good sensitivity in postmenopausal women and further endometrial sampling is not required if ET is $<5 \mathrm{~mm} .{ }^{26,37}$ Thus, both these studies contradict the present study.

Thus, after going through all these studies and observations in present study, it is emphasized that both ultrasonography and HPE done from endometrial curetting; complement each other as an effective screening method before proceeding to more painful, costly and invasive screening method.

\section{CONCLUSION}

From this study, it is concluded that the combined use of transvaginal ultrasonography and endometrial sampling for HPE as office procedure in postmenopausal women with postmenopausal bleeding may be the reliable diagnostic protocol for detecting endometrial disease like atrophic endometrium, endometrial hyperplasia and endometrial cancer.

It is suggested that when office sampling of endometrium is not feasible because of extreme cervical stenosis in postmenopausal women, transvaginal sonography is most reliable in identifying women who need further evaluation.

It is also concluded from this study that office sampling of endometrium with pipelle, endometrial polyps and submucosal myomas may be missed. Hence, these cases require correlation with TVS findings. It is suggested that if endometrial thickness is $5 \mathrm{~mm}$ or less, further investigations are not required but in cases of recurrent episodes of postmenopausal bleeding further investigations are indicated.

\section{Funding: No funding sources}

Conflict of interest: None declared

Ethical approval: The study was approved by the Institutional Ethics Committee

\section{REFERENCES}

1. Berek, Jonathan S. Berek and Novak's Gynecology. $14^{\text {th }}$ edition, $\mathrm{p} 491$.

2. Nicholson WK, Ellison SA, Grason H, Powe NR. Patterns of ambulatory care use for gynecologic conditions: a national study. Am J Obstet Gynecol. 2001;184:523-30.

3. Moodley M, Roberts C. Clinical pathway for the evaluation of postmenopausal bleeding with an emphasis on endometrial cancer detection. J Obstet Gynecol. 2004;24:736Y741.

4. Oehler MK, MacKenzie I, Kehoe S, Rees MC. Assessment of abnormal bleeding in menopausal women: an update. $\mathrm{J} \mathrm{Br}$ Menopause Soc. 2003;9:117-20.

5. Bosch TVD, Vandendael A, Van Schoubroek D, Wranz PAB, Lombard CJ. Combining vaginal ultrasonography and office endometrial sampling in the diagnosis of endometrial disease in postmenopausal women. Obstet Gynecol. 1995;85:349-5.

6. Oriel KA, Schrager S. Abnormal uterine bleeding. Am Fam Physician. 1999;60:1371-80.

7. Tahir MM, Bigrigg MA, Browning S. Brookes T, Phillip A, Smith A. Randomised controlled trial comparing transvaginal ultrasound, outpatient hysteroscopy and endometrial biopsy with inpatient hysteroscopy and curettage. Br J Obstet Gynaecol. 1999; 106:1259-64.

8. Hsu CY, Chen CP, Wang KL. Assessment of postmenopausal bleeding. Int $\mathrm{J}$ Gerontol. 2008;2(2):55-9.

9. Partridge EE, Shingleton HM, Menck HR. The National Cancer Data Base report on endometrial cancer. J Surg Oncol. 1996;61:111-23.

10. Weber AM, Belinson JL, Bradley LD, Piedmonte MR. Vaginal ultrasonography versus endometrial biopsy in women with postmenopausal bleeding. Am J Obstet Gynecol. 1997;177:924-9.

11. Goldstein SR, Nachtigall M, Synder JR, Nachtigall L. Endometrial assessment by vaginal ultrasonography before endometrial sampling in patients with post-menopausal bleeding. Am J Obstet Gynecol. 1990;163:119-23.

12. Gull B, Carlsson S, Karlsson B. Ylöstalo P, Milsom I, and Granberg S., Transvaginal ultrasonography of the endometrium in women with postmenopausal bleeding: Is it always necessary to performan endometrial biopsy? Am J Obstet Gynecol. 2000;182:509-15.

13. Fedele L, Bianchi S, Dorta M, Brioshi D, Zanotti F, Vercellini P. Transvaginal ultrasonography versus hysteroscopy in the diagnosis of uterine submucous myomas. Obstet Gynecol. 1991;77:745-8.

14. Doorn HCV, Opmeer BC, Burger CW, Duk MJ, Kooi GS, Mol BWJ. Inadequate office endometrial sample requires further evaluation in women with postmenopausal bleeding and abnormal ultrasound results. Int J Gynecol Obstet. 2007;99:100-4.

15. Nasri MN, Coast GJ. Correlation of ultrasound findings and endometrial histopathology in postmenopausal women. $\mathrm{Br} \mathrm{J}$ Obstet Gynecol. 1989;96:1333-8.

16. Goldstein SR. The role of transvaginal ultrasound or endometrial biopsy in the evaluation of the menopausal endometrium. American $\mathrm{J}$ Obstet Gynecol. 2009;201(1):5-11.

17. Alfhaily $F$ and Ayman AA. Ewies The First-Line Investigation of Postmenopausal Bleeding Transvaginal Ultrasound Scanning and Endometrial Biopsy May Be Enough. Int J Gynecol Cancer. 2009;19:892Y895. 
18. Dutch Society of Obstetrics and Gynaecology. Abnormal vaginal bleeding in post menopause: NVOG guideline, vol. 4. Utrecht, the Netherlands: Dutch Soc Obstet Gynecology; 1997.

19. Langer RD, Pierce JJ, Katherine, Anlan AOH, Susan, Johnson R, et al. Transvaginal ultrasonography compared with endometrial biopsy for the detection of endometrial disease $\mathrm{N}$ Engl $\mathrm{J}$ Med. 1997;337:1792-8.

20. Goldstein RB, Bree RL, Benson CB. Evaluation of the woman with postmenopausal bleeding: Society of Radiologists in Ultrasound-Sponsored Consensus Conference statement. J Ultrasound Med. 2001;20:1025Y1036.

21. Russell M, Choudhary M, Roberts $M$. Is an endometrial thickness of $\geq 4 \mathrm{~mm}$ on transvaginal ultrasound scan an appropriate threshold for investigation of postmenopausal bleeding?. Gynecol Surg. 2016;13(3):193-7.

22. Karlsson B, Granberg S, Wikland M, Yisstalo P, Torvid K, Marsal $\mathrm{K}$ et al. Transvaginal ultrasonography of the endometrium in women with postmenopausal bleeding-A Nordic multicenter study. Am J Obstet Gynecol. 1995;172:1488-94.

23. Bosch TVD, Schoubroeck DV, Ameye L, Huffel SV, Timmerman D. Ultrasound examination of the endometrium before and after Pipelle endometrial sampling Ultrasound. Obstet Gynecol. 2005;26:2836.

24. Ewies AA, Musonda P. Managing postmenopausal bleeding revisited: what is the best first lineinvestigation and who should be seen within 2 weeks? A cross-sectional study of 326 women. Euro J Obstet Gynecol Repro Bio. 2010;153:67-71.

25. Viswanathan M, Daniel S, Shailaja M, Nazeema A. Socio-demographic profile of patients with postmenopausal bleeding attending out-patient unit of a tertiary care centre. Sch J App Med Sci. 2014; 2(2C):681-4.

26. Kekre AN, Jose' $\mathrm{R}$ and Seshadri L. Transvaginal sonography of the endometrium in South Indian postmenopausal women Aus NZ. J Obstet Gynaecol. 1997;37(4):449-51.

27. Salman MC, Bozdag G, Dogan S and Yuce K. Role of postmenopausal bleeding pattern and women's age in the prediction of endometrial cancer Aus NZ J Obstet Gynaecol. 2013;53:484-8.

28. Giannella L, Mfuta K, Setti T, Cerami LB, Bergamini E, Boselli F. A risk-scoring model for the prediction of endometrial cancer among symptomatic postmenopausal women with endometrial thickness> $4 \mathrm{~mm}$. BioMed research international. 2014;2014.
29. Pal L, Lapensee L, Toth TL, Isaacson KB. Comparison of office hysteroscopy, transvaginal ultrasonography and endometrial biopsy in evaluation of abnormal uterine bleeding. JSLS. 1997;1:125-30.

30. Bruchim I, Shental TB, Altaras MM, Fishman A, Beyth Y, Tepper R, et al. Combination of endometrial thickness and time since menopause in predicting endometrial cancer in women with postmenopausal bleeding. Clin Ultrasound. 2004;32:219-24.

31. Ferrazzi E, Torri V, Trio D, Zannoni E, Filiberto S and Dordoni D. Sonographic endometrial thickness: Auseful test to predict atrophy in patients with postmenopausal bleeding. An Italian multicentre study. Ultrasound Obstet Gynecol. 1996:7;315-21.

32. Epstein E, Ramirez A, Skoog L and Valentin L. Dilatation and curettage fails to detect most focal lesions in the uterine cavity in women with postmenopausal bleeding. Acta Obstet Gynecol Scand. 2001;80:1131-6.

33. Gull B, Karlsson B, Milsom I, Granberg S. Can ultrasound replace dilation and curettage? A longitudinal evaluation of postmenopausal bleeding and transvaginal sonographic measurement of the endometrium as predictors of endometrial cancer. Am J Obstet Gynecol. 2003;188:401-8.

34. Tabor A, Watt HC, and Wald NJ. Endometrial Thickness as a Test for Endometrial Cancer in Women with Postmenopausal Vaginal Bleeding. Obstet Gynecol. 2002;99:663-70.

35. Minagawa Y, Sato S, Ito M, Onohara Y, Nakamoto S, Kigawa J. Transvaginal Ultrasonography and Endometrial Cytology as a Diagnostic Schema for Endometrial Cancer. Gynecol Obstet Invest. 2005;59:149-54.

36. Tsikouras P, Liberis V, Galazios G, Grapsas X, Kantari P, Papageorgiou S, et al. TV sonographic assessment in postmenopausal women with bleeding Euro J Gynecol Oncol. 2008;29(1):67-71.

37. Jacobs I, Maharaj AG, Burnell M, Manchanda R, Singh N, Sharma A. Sensitivity of transvaginal ultrasound screening for endometrial cancer in postmenopausal women: a case-control study within the UKCTOCS cohort. Lancet Oncol. 2011;12:3848.

Cite this article as: Sharma J, Dhiman B, Sud N, Kaushik A. Synergistic approach in diagnosing endometrial disease in women with postmenopausal bleeding. Int J Reprod Contracept Obstet Gynecol 2017;6:4081-9. 